\title{
The Induction of Staphylococcal $\alpha$-Toxin by Histidine
}

\author{
By A. B. DALEN \\ The University of Bergen, School of Medicine, The Gade Institute, \\ Department of Microbiology, Bergen, Norway
}

(Received 22 March 1972; revised 28 July 1972)

\begin{abstract}
SUMMARY
Addition of histidine to cultures of Staphylococcus aureus strain Wood 46 in a synthetic amino acid medium induced $\alpha$-toxin formation, intracellularly within Io min, and extracellularly within $15 \mathrm{~min}$. The induction was inhibited by actinomycin D, chloramphenicol, sodium azide and sodium nitrite. Histidinol behaved like histidine but several histidine analogues were without inductive properties. Histamine, which was metabolized to $N$-acetylhistamine, inhibited growth and $\alpha$-toxin production in media without histidine, but its effect was overcome by histidine or histidinol.

The culture fluids were examined by polyacrylamide gel electrophoresis. Precipitation with trichloracetic acid was used for concentration of the $\alpha$-toxin, active toxin being recovered from the precipitate by dissolving in urea followed by heat precipitation.

Three proteins appeared extracellularly in addition to $\alpha$-toxin after induction with histidine.
\end{abstract}

\section{INTRODUCTION}

Staphylococcal $\alpha$-toxin is an extracellular protein produced by most human strains of Staphylococcus aureus. It can exist in multiple molecular forms (Wadström, 1968), and has a lytic effect on artificial and various natural membranes (Weissmann, Sessa \& Bernheimer, I966). Although the subject of numerous studies, its mode of action is still unknown.

From the rapid appearance of $\alpha$-toxin both extra- and intracellularly during certain phases of growth, it has been suggested that it is an induced protein (Hendricks \& Altenbern, 1968). Dalen (1973) isolated a factor from yeast extract which stimulated early $\alpha$-toxin production and was identified as histidine. Glycine and serine also stimulated production of toxin, but only after prolonged incubation. It was suggested that histidine is an inducer of $\alpha$-toxin in staphylococci while the stimulating effect of serine and glycine might be related to their function as histidine precursors.

Further evidence for the function of histidine as an inducer of staphylococcal $\alpha$-toxin is now presented.

\section{METHODS}

Bacterial strain and incubation conditions. Staphylococcus aureus strain Wood 46 was propagated as indicated earlier (Dalen, I973). Bacteria, grown overnight ( 12 to $16 \mathrm{~h}$ ) in a Casamino acid medium (Dalen, I973), were collected by centrifuging and suspended in the synthetic amino acid medium (Dalen, I973) to about I mg dry wt bacteria/ml. After incubation for $\mathrm{I}$ to $2 \mathrm{~h}$ the bacteria were collected and resuspended to the desired concentration in fresh amino acid medium.

Haemolytic assay. Titration of extracellular $\alpha$-toxin and the definition of the unit were as before (Dalen, I973). 
Intracellular $\alpha$-toxin was liberated from the staphylococci by lysostaphin (a generous gift from Dr P. A. Tavormina, Mead-Johnson Research Center, Evansville, Indiana, U.S.A.). When $50 \mu \mathrm{g}$ of lysostaphin, dissolved in $\mathrm{I} \mathrm{ml}$ of a buffer proposed by the producer, i.e. $0.05 \mathrm{M}$-tris- $\mathrm{HCl}$ containing $0.145 \mathrm{M}$-sodium chloride $\left(\mathrm{pH}_{7.2}\right)$, were added to $\mathrm{I}$ to $3 \mathrm{mg}$ dry wt bacteria, lysis was complete within Io to $15 \mathrm{~min}$ at $37^{\circ} \mathrm{C}$, but incubation was normally for $30 \mathrm{~min}$. Cell debris was removed by centrifuging ( $1000 \mathrm{~g}$ for $10 \mathrm{~min}$ ) before titrating the liberated toxin.

Measurement of bacterial cell mass from fluid cultures. This was described by Dalen (1972).

Protein determination. This was done by the Folin-Ciocalteau method (Lowry, Rosebrough, Farr \& Randall, 195I), using crystalline serum albumin as standard.

Concentration of extracellular proteins by trichloroacetic acid (TCA) precipitation. TCA was added to a final concentration of $5 \%(\mathrm{w} / \mathrm{v})$ to culture fluids freed of bacteria by centrifuging and Millipore filtration (pore size $0.45 \mu \mathrm{m}$ ). When the protein content was less than about $5 \mu \mathrm{g} / \mathrm{ml}$, a slurry of cellulose (cellulose powder MN 300, Macherey, Nagel \& Co., Düren, Germany) was added to a final concentration of 50 to $100 \mathrm{mg} / \mathrm{r} 00 \mathrm{ml}$ to aid precipitation and minimize losses. After standing at $+4{ }^{\circ} \mathrm{C}$ for $2 \mathrm{~h}$ the precipitate was centrifuged down, washed twice with $99 \%$ ethanol and dried in a desiccator. As indicated under Results, some of the proteins could be extracted from the precipitate by tris-chloride buffer $(0.05 \mathrm{M}$, $\mathrm{pH} 7.5$; the usual quantity being $1 \mathrm{ml}$ buffer $/ 250 \mathrm{ml}$ fluid precipitated). The residual precipitate containing most of the $\alpha$-toxin was completely soluble in the same buffer containing $8 \mathrm{M}$-urea (I to $2 \mathrm{ml} / \mathrm{I} 000 \mathrm{ml}$ fluid precipitated).

Polyacrylamide gel electrophoresis. Analytical electrophoresis was carried out in glass tubes in a Shandon apparatus (Shandon Scientific Co. Ltd, London). The same buffer (0.37 M-tris-glycine, $\mathrm{pH} 9.5$ ) was used in the gel and in the electrode vessels (Hjertén, Jersted $\&$ Tiselius, 1965). Urea when included was at a gel concentration of $5 \mathrm{M}$. The total acrylamide concentration was $7.5 \%$, gels being polymerized with ammonium persulphate and $N, N, N^{\prime}$ $N^{\prime}$-tetramethylethylenediamine. The dissolved precipitates or the cellulose slurries were layered on top of the gels, and a constant current of $3 \mathrm{~mA}$ per tube at a potential of about I $20 \mathrm{~V}$ was applied until the tracking dye, bromophenol blue, had reached the lower, anodic end of the tube. Gels were stained with $\mathrm{I} \%(\mathrm{w} / \mathrm{v})$ amido black in $7 \%(\mathrm{v} / \mathrm{v})$ acetic acid, destained in $7 \%$ acetic acid, and scanned with a Photovolt TLC Densitometer Model 530 (Photovolt, New York, N.Y., U.S.A.). Haemolytic activity was located in discs I mm thick incubated on rabbit blood agar.

Similar discs I to $2 \mathrm{~mm}$ thick were used for immuno-diffusion experiments.

Immunization of rabbits. The synthetic medium with a 20 times higher concentration of amino acids, and with $5 \mathrm{~mm}$-serine and histidine, was used to prepare the vaccine. Bacteria were grown in a small volume of this medium in dialysis bags laid on plates of the same medium solidified with agar. They were incubated for $24 \mathrm{~h}$ at $37^{\circ} \mathrm{C}$ in air containing $20 \%$ $\mathrm{CO}_{2}$. Polyacrylamide gel electrophoresis of the fluid revealed ${ }_{5} 5$ different protein bands. It was treated with I \% formalin (w/v) for $24 \mathrm{~h}$, then dialysed against phosphate-buffered saline (PBS); the protein content was $850 \mu \mathrm{g} / \mathrm{ml}$. Rabbits were immunized with this toxoid by injecting subcutaneously $0.5 \mathrm{ml}$ twice the first week and I $\mathrm{ml}$ twice the second week. In the third week I ml was given subcutaneously and two doses of $0.5 \mathrm{ml}$ intravenously. The animals were bled one week after the last injection. The immune serum gave four major and several weaker precipitation lines on diffusion in agar against non-toxoided antigen. Immunoelectrophoresis in veronal buffer, $\mathrm{pH} 8 \cdot 6$, gave seven precipitation lines.

Chemicals. Amino acids were obtained from Nutritional Biochemicals, Cleveland, Ohio, U.S.A. Other chemicals were analytical grade reagents from E. Merck, Darmstadt, Ger- 


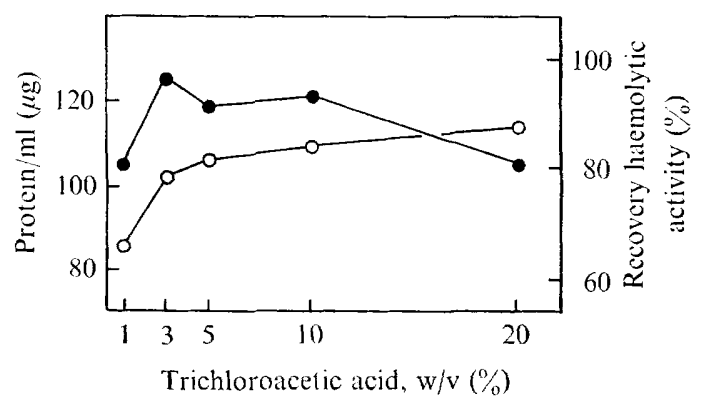

Fig. I. Protein precipitated from culture fluids with different concentrations of trichloroacetic acid, 9 , and recovery of haemolytic activity by treatment with $8 \mathrm{M}$-urea, $\bigcirc$.

many; Koch-Light Laboratories Ltd, Colnbrook, Buckinghamshire; Sigma Chemical Company, St Louis, Missouri, U.S.A.; and British Drug Houses Ltd, Poole, Dorset.

\section{RESULTS}

Concentration of extracellular protein and purification of $\alpha$-toxin

Rotary evaporation, ultrafiltration and ammonium sulphate precipitation have been used to concentrate supernatants from staphylococcal cultures (Wadström, 1968). A recent method for purification of $\alpha$-toxin (Arbuthnott, Freer \& Bernheimer, 1967) involved ammonium sulphate precipitation followed by continuous flow electrophoresis. The toxin was then aggregated by brief heating to $60^{\circ} \mathrm{C}$ followed by disaggregation in $8 \mathrm{M}$-urea with recovery of active $\alpha$-toxin in high yield.

In the present work, culture filtrates contained little protein. Precipitation by ammonium sulphate was unsatisfactory, as was that by methanol or ethanol at various concentrations and ionic strengths. Ultrafiltration gave good results but was time consuming.

Trichloroacetic acid (TCA) is an efficient protein precipitant, but is usually considered to cause extensive denaturation. However, active $\alpha$-toxin could be extracted from TCA precipitates in good yield, as described in Methods. The amount of protein precipitated and toxin recovered, in relation to final concentration of TCA is shown in Fig. I. The dried TCA precipitate was partially soluble in $0.05 \mathrm{M}$-tris-chloride buffer, $\mathrm{pH} 7.5$. Polyacrylamide gel electrophoresis of the extract showed ro protein bands (Fig. $2 a$ ), but the haemolytic activity was low. The undissolved part of the precipitate was soluble in tris buffer containing $8 \mathrm{M}$ urea, and was strongly haemolytic.

The urea-soluble material gave three protein bands on electrophoresis in polyacrylamide gels with urea (Fig. $2 b$ ) and three precipitation lines on immuno-diffusion in agar. When the solution, diluted by tris buffer to a urea concentration of $0.8 \mathrm{M}$, was heated in a $2 \mathrm{ml}$ volume in a water-bath at $60{ }^{\circ} \mathrm{C}$ for 2 to $3 \mathrm{~min}$, a white precipitate formed. Electrophoresis of the precipitate, redissolved in tris-urea, showed that only the fastest moving protein remained in solution (Fig. 2 c) giving a single precipitation line on immuno-diffusion.

The efficiency of the heat precipitation was highly dependent on the protein concentration. High concentrations precipitated on merely diluting the urea solution, but with low concentrations heat treatment gave only partial precipitation.

Haemolytic activity was confined to the fastest moving of the two proteins precipitated by the heat treatment. On immuno-diffusion they gave precipitation lines crossing with one spur. Two protein bands appeared in acrylamide gel electrophoresis with sodium dodecyl sulphate ( $\mathrm{I} \cdot \mathrm{O}$ in the sample and $\mathrm{O} \cdot \mathrm{I} M$ in the gel). 


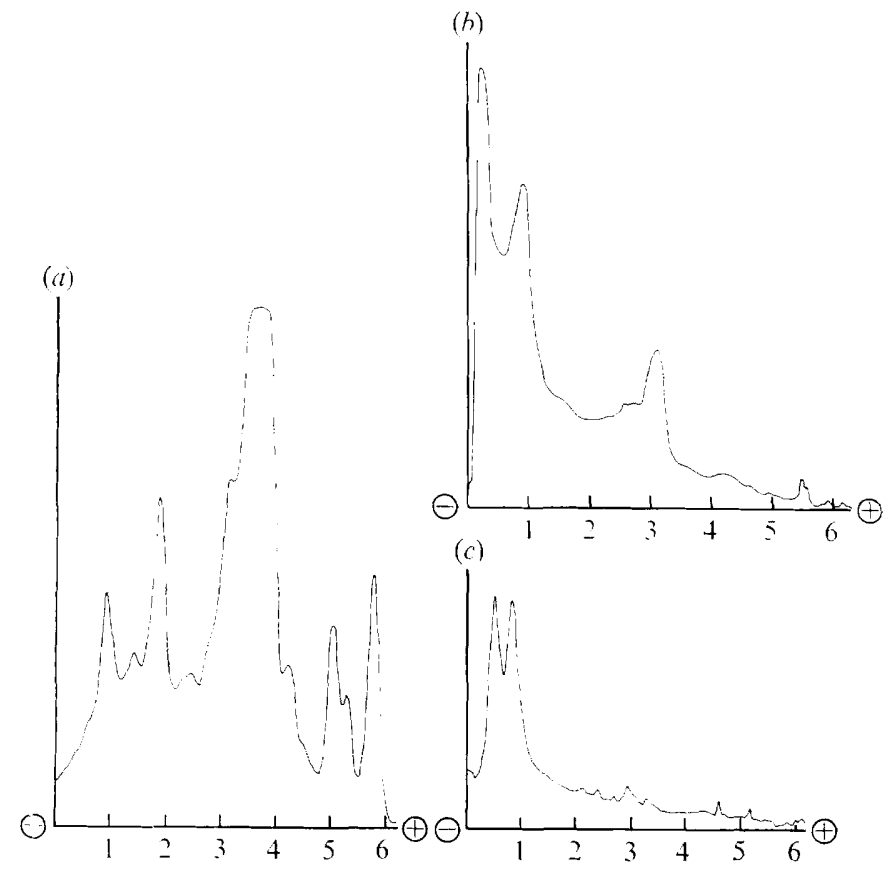

Fig. 2. Polyacrylamide electrophoresis of extracellular proteins from Staphylococcus aureus precipitated by trichloroacetic acid $5 \%(\mathrm{w} / \mathrm{v})$. Ordinate represents scanning density; abscissa, distance $(\mathrm{cm})$ from top of gel. (a) Extract of precipitate in $0.05 \mathrm{M}$-tris-HCl buffer, $\mathrm{pH} \mathrm{7.5.} \mathrm{(b)} \mathrm{Remaining} \mathrm{precipitate}$ dissolved in $8 \mathrm{M}$-urea in same buffer. (c) Precipitate from $(b)$ on heating for 2 min at $60^{\circ} \mathrm{C}$, dissolved in $8 \mathrm{M}$-urea. The leading band on the anode side is $\alpha$-toxin.

\section{Production of intracellular $\alpha$-toxin}

Variable amounts of intracellular $\alpha$-toxin were found in bacteria grown overnight in Casamino acid medium. In bacteria freshly suspended in the amino acid medium, no intracellular toxin could be demonstrated. It appeared shortly before extracellular toxin, after a time lag, which depended on inoculum size; when this was small, toxin was formed only during the late phase of growth.

The disappearance of intracellular $\alpha$-toxin when bacteria were transferred to fresh amino acid medium was assumed to indicate that the bacteria had been brought to a non-induced state, and a short pre-incubation in amino acid medium was therefore always included.

When I mM-histidine was added to the medium, $\alpha$-haemolytic activity could be detected intracellularly after to min with an inoculum of $2 \mathrm{mg}$ dry wt bacteria/ml, but its level was generally low (maximum, 3 haemolytic units/mg dry wt bacteria).

\section{Extracellular toxin production and its relation to bacterial cell mass}

As shown earlier (Dalen, 1972) the addition of histidine to the amino acid medium gave a rapid production of extracellular $\alpha$-toxin. As good aeration enhanced this effect, the cultures were incubated in shallow layers on a rotary shaker. The amount of $\alpha$-toxin released extracellularly depended on the size of the inoculum used (Fig. 3). During maximum production the amount of toxin formed $/ \mathrm{mg}$ dry wt of bacteria $/ \mathrm{ml} / \mathrm{h}$ was independent of cell mass, and was about 40 haemolytic units. Maximal production occurred after about 90 min with an inoculum of $2 \mathrm{mg}$ dry wt bacteria/ml, but later with smaller inocula. Further incubation 


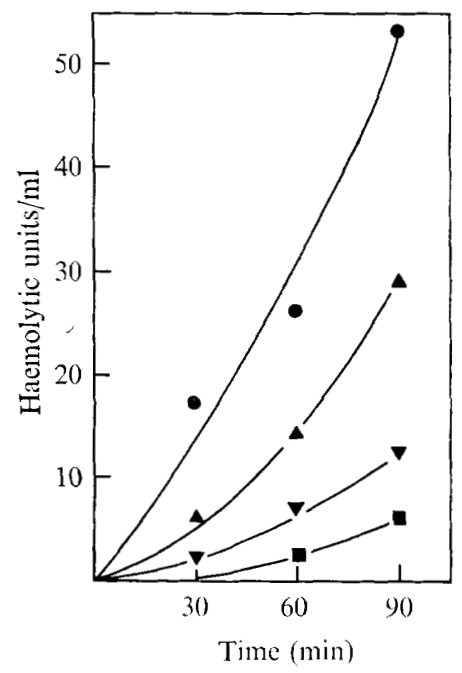

Fig. 3. The relation of initial cell mass to the stimulating effect of histidine on extracellular $\alpha$-toxin production. Histidine, I mM, in amino acid medium. Inoculum, dry wt bacteria $/ \mathrm{ml}: 2000 \mu \mathrm{g} / \mathrm{ml}, \mathbf{0}$; $\mathrm{I} 000 \mu \mathrm{g} / \mathrm{ml}, \mathbf{\Delta} ; 500 \mu \mathrm{g} / \mathrm{ml}, \nabla$; and $250 \mu \mathrm{g} / \mathrm{ml}$,
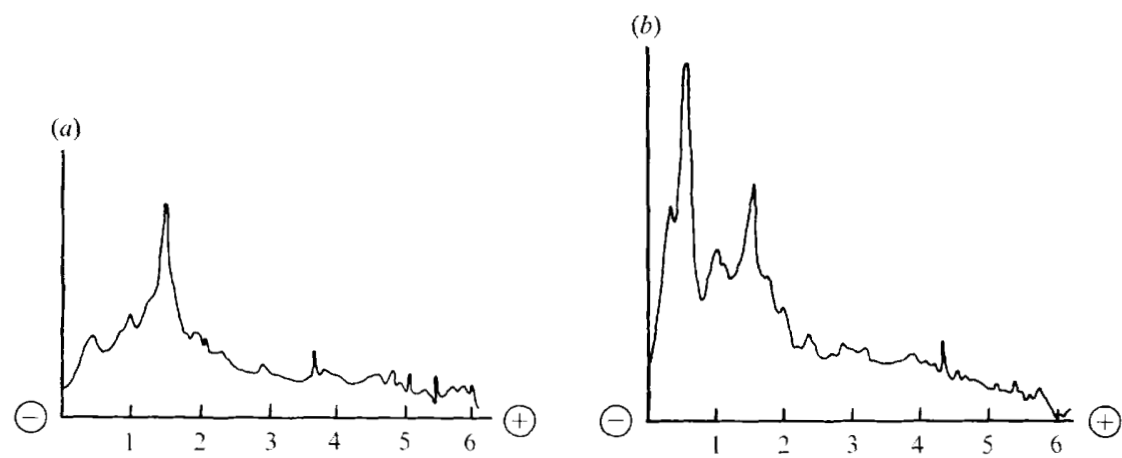

Fig. 4. Polyacrylamide gel electrophoresis of extracellular proteins precipitated with trichloroacetic acid from cultures in amino acid medium. Incubation time $90 \mathrm{~min}$. The precipitates were dissolved in $8 \mathrm{M}$-urea, $0.05 \mathrm{M}$-tris- $\mathrm{HCl}$ buffer, $\mathrm{pH} \mathrm{7.5}$. The gels contained $5 \mathrm{M}$-urea. Ordinate represents scanning density; abscissa, distance $(\mathrm{cm})$ from top of gel. (a) Control culture. (b) Culture induced with histidine, I mM. The highest peak is $\alpha$-toxin.

resulted in a gradual loss of haemolytic activity, presumably due to denaturation. It was shown earlier that serine stimulated $\alpha$-toxin production after prolonged incubation. Serine and histidine together in various concentrations gave a slightly higher yield of toxin than did histidine alone.

\section{Polyacrylamide gel electrophoresis of amino acid medium supernatants}

Bacteria, I $\mathrm{mg}$ dry $\mathrm{wt} / \mathrm{ml}$, were incubated in $100 \mathrm{ml}$ amino acid medium with and without I mM-histidine for $90 \mathrm{~min}$ and the filtered supernatants were precipitated by TCA and assayed. The control culture contained $\mathrm{I} \cdot 6 \mu \mathrm{g}$ protein $/ \mathrm{ml}$ supernatant, and that from the histidine-induced culture $2.6 \mu \mathrm{g} / \mathrm{ml}$. On electrophoresis on polyacrylamide gel with urea the control culture gave only one protein band (Fig. $4 a$ ); the histidine-induced culture gave in addition one major and three minor protein bands (Fig. $4 b$ ). Haemolytic activity was confined to the major band. 


\section{$\alpha$-Toxin production in partly lysed bacteria}

The early low production of $\alpha$-toxin after addition of histidine might be due to an initial slow transport of histidine into the cell or to a delayed release of toxin into the medium. This was studied in various experiments with cells partially damaged by treating with $\mathrm{I}, 2$ and $5 \mu \mathrm{g}$ lysostaphin/ml for various times before incubation with histidine in the amino acid medium, and also in the same medium containing lysostaphin. Lysis of bacteria was demonstrated in both types of experiment by the appearance of nucleic acid in the medium and by the presence of large Gram-negative bodies. Although $\alpha$-toxin was produced under these conditions, no shortening of the lag period could be demonstrated.

\section{Effect of histidine analogues on $\alpha$-toxin production}

When I-methylhistidine (I $\mathrm{mm}$ ) was incubated for $120 \mathrm{~min}$ with I $\mathrm{mg}$ dry wt bacteria $/ \mathrm{ml}$ the haemolytic titre was $15 \%$ of that in a similar culture containing I mM-histidine. 3-Methylhistidine, 2-thiolhistidine, urocanic acid and histamine diphosphate in the same concentration did not stimulate $\alpha$-toxin production. Histidinol had a stimulating effect equal to that of histidine. The four inactive compounds ( $\mathrm{I} \mathrm{mM}$ ) were also tested in stagnant cultures incubated for $24 \mathrm{~h}$ with inocula of $30 \mu \mathrm{g}$ dry wt bacteria $/ \mathrm{ml}$. The first three had no effect by themselves, nor did they alter the stimulating effect of serine in the late phase of growth (Dalen, 1973). Histamine diphosphate inhibited both growth and $\alpha$-toxin production. Thus, at $0.05 \mathrm{~mm}$ it reduced them to $20 \%$ and $10 \%$ respectively of the control values. Histidine or histidinol reversed both inhibitory effects. The findings indicated that histamine interfered with the de novo synthesis of histidine. A preliminary analysis of bacterial extracts and supernatants from histamine cultures using the gel filtration and thin-layer chromatography procedures described before (Dalen, 1973) showed that histamine was metabolized to $N$-acetylhistamine, which was found both intra- and extracellularly. There was no evidence of intracellular accumulation of histidine precursors.

\section{Effect of metabolic inhibitors}

Chloramphenicol suppressed the histidine-induced production of $\alpha$-toxin (Fig. 5), the concentration required being highly dependent on the inoculum size. Inhibitors of oxidative phosphorylation also suppressed it, 2,4-dinitrophenol (Fig. 6) being five times more effective than sodium azide.

The induction of toxin with an inoculum of I mg dry wt bacteria/ml was completely suppressed by $0.7 \mu \mathrm{g}$ actinomycin $\mathrm{D} / \mathrm{ml}$, the lowest concentration tested.

\section{Tests for catabolite repression}

Glucose represses the induced enzymes $\beta$-galactosidase and tryptophanase in Escherichia coli, and cyclic $3^{\prime}, 5^{\prime}$-AMP restores the synthesis of the repressed enzymes (Perlman \& Pastan, I968). Histidine has a sparing effect on the purine pool (Ames \& Garry, 1959), and whether it has a similar regulatory mechanism for $\alpha$-toxin production was tested both directly and indirectly.

Bacteria partially lysed by lysostaphin, as described earlier, were exposed to adenine, AMP, ADP, ATP and cyclic $3^{\prime}, 5^{\prime}$-AMP without significant effect on $\alpha$-toxin production.

In the tests for catabolite repression bacteria, I $\mathrm{mg}$ dry $\mathrm{wt} / \mathrm{ml}$ were grown in amino acid medium, containing $0.2 \mathrm{M}$-glycerol or $0 . \mathrm{I}$ M-glucose as carbon source, for $2 \mathrm{~h}$. Bacteria were collected, washed in PBS, and resuspended in fresh amino acid medium with glucose or glycerol as before. The cultures were induced with I mM-histidine, incubated on a rotary 


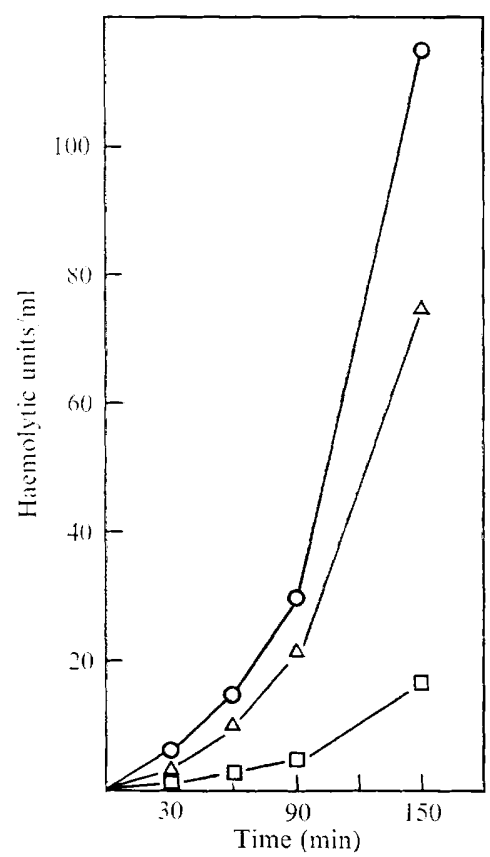

Fig. 5

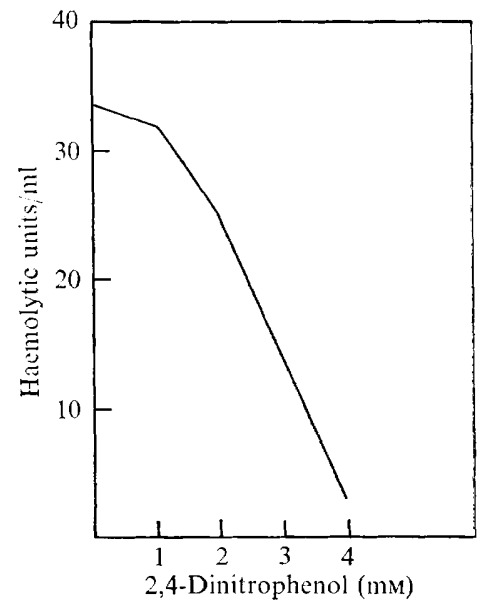

Fig. 6

Fig. 5. Effect of chloramphenicol on histidine-induced production of $\alpha$-toxin. Histidine, I mM. Inoculum, I mg dry wt bacteria/ml. Control, $\bigcirc$; I00 $\mu \mathrm{g}$ chloramphenicol $/ \mathrm{ml}, \Delta ; 500 \mu \mathrm{g}$ chloramphenicol $/ \mathrm{ml}, \square$.

Fig. 6. Effect of 2,4-dinitrophenol on histidine-induced $\alpha$-toxin production. Histidine, I mm. Inoculum, I $\mathrm{mg}$ dry wt bacteria/ml. Incubation time $90 \mathrm{~min}$.

shaker and tested for haemolytic activity after 30 and $60 \mathrm{~min}$. There was no significant difference in haemolytic titre between cultures on the two carbohydrate sources, but after several hours it was higher in that containing glucose. The increased yields in these cultures coincided with a drop in $\mathrm{pH}$ to below $6 \cdot 0$.

\section{DISCUSSION}

Concentration by TCA precipitation, as used here, compares favourably with earlier methods for concentration and purification of staphylococcal extracellular proteins. In a more complex purification procedure (Arbuthnott et al. 1967) the final heat denaturation step gave only $\alpha$-toxin. With our method it gave two proteins. The non-haemolytic fraction has not yet been identified but the lack of identity with active toxin in immuno-diffusion does not exclude the possibility that it is a different form of it.

The rapid appearance of both intra- and extracellular $\alpha$-toxin on addition of histidine to the amino acid medium was very sensitive to actinomycin $\mathrm{D}$, indicating that de novo synthesis of protein occurred. At least three extracellular proteins besides $\alpha$-toxin were formed. They were less abundant extracellularly, but, since their intracellular concentrations are unknown, no conclusions can be drawn about their rate of synthesis compared with that of $\alpha$-toxin.

Histidine synthesis is coupled with ATP synthesis, so its addition will have a sparing effect on the purine pool. Since the purine pool and the intracellular level of cyclic $3^{\prime}, 5^{\prime}$-AMP have an effect on other inducible proteins, histidine might possibly affect $\alpha$-toxin formation 
through such a mechanism. However, the addition of various purines, including cyclic AMP, both to intact and partially lysed bacteria had no effect on $\alpha$-toxin formation. The lack of repression by glucose also provided indirect evidence against this hypothesis, since glucose repression is mediated through cyclic AMP in the case of the two inducible enzymes $\beta$ galactosidase and tryptophanase in Escherichia coli (Perlman \& Pastan, 1968). Glucose repression of $\beta$-galactosidase has also been demonstrated in staphylococci (McClatchy \& Rosenblum, 1963).

The initial low production of $\alpha$-toxin resembles the latent period when lactose induces $\beta$-galactosidase in Escherichia coli; it seems that a $\beta$-galactosyl alcohol formed from lactose, rather than lactose itself, is the inducer (Burstein, Cohn, Kepes \& Monod, 1965). It may be relevant that, on genetic evidence, histidyl tRNA is more directly involved in the repression of the histidine operon in Salmonella than is histidine (Silbert, Fink \& Ames, 1966). The latency observed in histidine-induced $\alpha$-toxin production may be due to a derivative, rather than histidine itself, being the true inducer.

The reversal by histidine and histidinol of the inhibition of growth and toxin production by histamine diphosphate supports the view that the late stimulating effect of serine on $\alpha$-toxin production is related to the action of serine as a precursor of histidine. From studies with Salmonella it is known that the first enzyme in the histidine pathway, phosphoribosylATP pyrophosphorylase, is regulated by feed-back inhibition by histidine (Martin, 1963). Since no phosphorylated histidine diphosphate was added, this would suggest that histamine, or its derivative $N$-acetyl histamine, inhibited the first enzyme in the histidine synthesis pathway. The enzyme in Salmonella is strongly inhibited by histidine in vitro, but histamine is non-inhibitory (Martin, I963).

The stimulation of tetanus toxin output by histidine peptides (Mueller \& Miller, 1956) is of particular relevance to this work. Free histidine was utilized for growth, but did not stimulate toxin production even in large amounts. Under toxigenic conditions the organism contained a peptidase which hydrolysed the histidine peptides in the medium (Miller, Gray \& Eaton, I960), those peptides associated with the highest yield of toxin being the most readily hydrolysed. At the same time peptidase formation could not be induced without toxin formation. Kihara \& Snell (I955) suggested that the superiority of histidine peptides, compared with histidine, might be due to microbial degradation of the amino acid. The tetanus toxin appeared after several hours and reached a maximum after $24 \mathrm{~h}$. By contrast staphylococcal $\alpha$-toxin production after $24 \mathrm{~h}$ with histidine and small inocula was unimpressive and considerably lower than with serine. Information on the effect of histidine peptides on $\alpha$-toxin formation, and on the decreased synthesis of $\alpha$-toxin at an alkaline $\mathrm{pH}$, would further elucidate the regulation of $\alpha$-toxin production, and such studies are now in progress.

\section{REFERENCES}

AMES, B. N. \& GARRY, B. ( I959). Coordinate repression of the synthesis of four histidine biosynthetic enzymes by histidine. Proceedings of the National Academy of Sciences of the United States of America 45, 1453.

Arbuthnott, J. P., Freer, J. H. \& Bernheimer, A. W. (I967). Physical states of staphylococcal $\alpha$-toxin. Journal of Bacteriology 94, I I $70-1$ I 77.

Burstein, C., Cohn, M., Kepes, A. \& Monod, J. (1965). Rôle du lactose et de ses produits métaboliques dans l'induction de l'opéron lactose chez Escherichia coli. Biochimica et biophysica acta 95, 634-639.

DALEN, A. B. (1973). Effect of amino acids and a factor from yeast extract on $\alpha$-toxin formation in Staphylococcus aureus. Journal of General Microbiology 74, 53-60.

Hendricks, C. W. \& Altenbern, R. A. (1968). Studies on the synthesis of staphylococcal alpha toxin. Canadian Journal of Microbiology $14,1277-128 \mathrm{I}$. 
HJertÉn, S., Jerstedt, S. \& Tiselius, A. (I965). Some aspects of the use of 'continuous' and 'discontinuous' buffer systems in polyacrylamide gel electrophoresis. Analytical Biochemistry II, 219-223.

Kinara, H. \& SNell, E. E. (I955). Peptides and bacterial growth. III. Relation to inhibitions by thienylalanine, ethionine, and canavanine. Journal of Biological Chemistry 212, 83-94.

Lowry, O. H., Rosebrough, N. J., Farr, A. L. \& Randall, R. J. (195I). Protein measurement with the Folin phenol reagent. Journal of Biological Chemistry I93, 265-275.

McClatchy, J. K. \& Rosenblum, E. D. (I963). Induction of lactose utilization in Staphylococcus aureus. Journal of Bacteriology 86, I2 I I-12 I5.

Madoff, M. A. (1965). The staphylococci: ecological perspectives. Annals of the New York Academy of Sciences $128,122$.

MARTIN, R. G. (1963). The first enzyme in histidine biosynthesis: the nature of feedback inhibition by histidine. Journal of Biological Chemistry 238, 257-268.

Miller, P. A., Gray, C. T. \& Eaton, M. D. (I960). Formation and action of a peptidase which hydrolyzes histidine peptides required in tetanus toxin synthesis. Journal of Bacteriology 79, 95-102.

Mueller, J. H. \& Miller, P. A. (1956). Essential role of histidine peptides in tetanus toxin production. Journal of Biological Chemistry 223, 185--I94.

Perlman, R. \& Pastan, I. (1968). Cyclic $3^{\prime} 5^{\prime}$-AMP: stimulation of $\beta$-galactosidase and tryptophanase induction in E. coli. Biochemical and Biophysical Research Communications 30, 656-664.

Silbert, D. F., Fink, G. R. \& AMEs, B. N. (1966). Histidine regulatory mutants in Salmonella typhimurium. A class of regulatory mutants deficient in tRNA for histidine. Journal of Molecular Biology 22, 335-347.

WadsTRöM, T. (1968). Studies on the extracellular proteins from Staphylococcus aureus. IV. Separation of $\alpha$-toxin by isoelectric focusing. Biochimica et biophysica acta $\mathbf{1 6 8}, 228-242$.

Weissmann, G., Sessa, G. \& Bernheimer, A. W. (1966). Staphylococcal alpha-toxin: Effects on artificial lipid spherules. Science, New York 154, 772-774. 